\title{
Faktor Risiko Terjadinya Demam Neutropenia pada Anak Leukemia Limfoblastik Akut
}

\author{
MMDEAH Hapsari, Moedrik Tamam, Pradipto Satrio \\ Departemen Ilmu Kesehatan Anak RSUP dr. Kariadi Fakultas Kedokteran Universitas Diponegoro, \\ Semarang
}

\begin{abstract}
Latar belakang. Demam neutropenia merupakan suatu sindrom yang terdiri dari dua gejala, yaitu adanya demam dan neutropenia yang didefinisikan sebagai absolute neutrophils count/ANC $<500 \mathrm{sel} / \mathrm{mm}^{3}$, yang seringkali muncul pada pasien keganasan akibat penyakit maupun pengobatannya. Leukemia limfoblastik akut merupakan keganasan hematologi dengan kemungkinan sembuh yang cukup tinggi, adanya komplikasi demam neutropenia meningkatkan angka mortalitas.
\end{abstract}

Tujuan. Mencari faktor risiko terjadinya demam neutropenia pada LLA

Metode. Studi pada 26 kasus anak yang dipilih secara consecutive sampling dan 26 kontrol. Kasus adalah pasien LLA yang menderita demam neutropenia sedangkan kontrol pasien LLA yang tidak demam neutropenia. Faktor risiko demam neutropenia pada anak dengan LLA yang diteliti meliputi dosis terapi sitostatika risiko tinggi, status gizi, status sosial ekonomi, durasi pemakaian infus dan hipoalbuminemia. Statistik yang digunakan adalah uji t, Chi square, dan analisis multivariat dengan uji regresi logistik berganda..

Hasil. Studi univariat status sosial ekonomi miskin merupakan faktor risiko terhadap kejadian demam neutropenia dengan nilai OR sebesar 4,591 kali dibandingkan pasien yang tidak miskin ( $\mathrm{p}=0,032$; $95 \% \mathrm{CI}=1,078-15,086)$. Terapi sitostatika risiko tinggi $(\mathrm{p}=0,109 ; 95 \% \mathrm{CI}=0,09-1,308)$, status gizi $(\mathrm{p}=0,382$; $95 \% \mathrm{CI}=0,439-4,699)$, rerata durasi pemakaian infus $(\mathrm{p}=0,5 ; 95 \% \mathrm{CI}=0,442-4,790)$ dan hipoalbuminemia $(\mathrm{p}=-0,271 ; 95 \% \mathrm{CI}=0,522-5,969)$ bukan risiko terhadap kejadian demam neutropenia. Analisis multivariat tidak didapatkan adanya faktor risiko yang berpengaruh secara bermakna terhadap kejadian demam neutropenia $(\mathrm{p}>0,05)$

Kesimpulan. Pasien LLA dengan sosial ekonomi rendah berisiko tinggi terhadap demam neutropenia. Sari Pediatri 2013;15(1):39-45.

Kata kunci: demam neutropenia, leukemia limfoblastik akut, faktor risiko

Alamat korespondensi:

Dr Pradipto Satrio, Sp.A. Departemen Ilmu Kesehatan Anak RSUP dr. Kariadi. Jl. dr.Soetomo no. 16-18 Semarang. E-mail: diptosn@gmail.com
L eukemia Limfoblastik Akut (LLA) merupakan penyakit keganasan sel darah yang berasal dari sumsum tulang, ditandai oleh proliferasi sel-sel darah putih dengan manifestasi sel-sel limfoblas dalam darah tepi. ${ }^{1}$ Demam neutropenia 
merupakan suatu sindrom yang terdiri dari 2 gejala, yaitu demam yang didefinisikan sebagai temperatur oral $\geq 38,3^{\circ} \mathrm{C}$ sekali pengukuran, atau temperatur $\geq 38^{\circ} \mathrm{C}$ untuk pengukuran selama 1 jam terus-menerus, atau pada 2 kali pengukuran dengan jarak minimal 12 jam, ${ }^{2-6}$ dan neutropenia yang didefinisikan sebagai hitung neutrofil total (absolute neutrophils count ANC) $<500 \mathrm{sel} / \mathrm{mm}^{3}$. Demam neutropenia adalah penyakit yang self-limited, seringkali iatrogenik yang muncul pada pasien kanker maupun pengobatannya. ${ }^{5}$ Demam neutropenia termasuk kegawatan di bidang hematologi karena penurunan jumlah neutrofil sebagai salah satu pertahanan tubuh utama terhadap mikroba, pasien menjadi sangat rentan terhadap infeksi berat dan kematian. Pasien demam neutropenia dengan atau tanpa gejala merupakan keadaan potensial yang mengancam hidup.

Penyebab demam neutropenia tersering adalah infeksi flora normal endogen, terutama bakteria aerobik Gram negatif yang berada di saluran pencernaan, mukosa, maupun permukaan kulit. ${ }^{7}$ Risiko infeksi semakin meningkat seiring penurunan jumlah neutrofil ketika jumlah neutrofil antara $100-500 / \mathrm{mm}^{3}$ peningkatan tingkat infeksi dari 0,5 menjadi 5 per 100 hari, apabila kurang dari $100 / \mathrm{mm}^{3} 16 \%-20 \%$ pasien menjadi sepsis. ${ }^{8}$ Angka mortalitas demam neutropenia berbeda pada masing-masing rumah sakit, tetapi umumya berkisar sekitar 30\%-64\%., , $9,10^{-10}$

Tujuan penelitian untuk mencari faktor risiko terjadinya demam neutropenia pada pasien LLA pada anak umur 1 sampai 14 tahun di Indonesia. Risiko yang diduga berpengaruh terhadap terjadinya demam neutropenia yang akan diteliti meliputi dosis terapi sitostatik, siklus kemoterapi, status gizi, status sosial ekonomi, lama pemakaian infus, dan kadar albumin.

\section{Metode}

Penelitian kasus kontrol dengan kelompok kasus adalah pasien demam neutropenia pada LLA, sedangkan kelompok kontrol adalah pasien LLA yang tidak menderita demam neutropenia. Populasi penelitian adalah semua pasien LLA berumur 1-14 tahun yang dirawat di Bangsal Hematologi Anak RSUP dr Kariadi, Semarang selama bulan April 2010 - Juni 2011. Wawancara dan penelusuran catatan medik dilakukan untuk mencari faktor risiko. Kriteria inklusi adalah anak yang dirawat di Bangsal Hematologi Ilmu
Kesehatan Anak RSUP dr. Kariadi, Semarang. Kriteria eksklusi meliputi anak yang menderita infeksi HIV/ AIDS dan sindrom Down secara klinis. Penelitian menggunakan perbandingan kasus dan kontrol 1:1, jumlah kontrol 26, sehingga jumlah kasus dan kontrol secara keseluruhan adalah 52 .

Pemilihan subjek secara consecutive sampling, yaitu berdasarkan kedatangan subjek penelitian di RSUP Dr. Kariadi, Semarang. Subjek kasus yang memenuhi kriteria penelitian akan diikutsertakan dalam penelitian, kemudian mencari kontrol yang sama dengan karakteristik kasus. Anak yang masuk kriteria inklusi kemudian dilakukan anamnesis dengan ibu/keluarga terdekat yang merawat mengenai karakteristik umum (jenis kelamin, umur, berat badan, tinggi badan, status gizi, status sosial ekonomi), dan riwayat penyakit. Pasien kemudian melengkapi informasi dosis terapi sitostatik, kadar albumin, dan durasi pemakaian infus. Data dianalisis secara inferensial, meliputi analisis bivariat dan multivariat. Analisis bivariat menggunakan Pearson $\mathrm{x}^{2}$, sedangkan analisis multivariat menggunakan uji regresi logistik. Batas kemaknaan yang digunakan $\alpha=5 \%, C I=95 \%$ dan power $80 \%$.

\section{Hasil}

Diperoleh 52 subjek LLA yang terbagi menjadi 2 kelompok, masing-masing 26 subjek. Rerata usia kelompok kasus 6,02 tahun dan kontrol 6,22 tahun, rentang usia 1 tahun 5 bulan sampai 14 tahun 11 bulan. Rerata status gizi subjek berdasarkan rerata IMT menunjukkan hasil yang normal, tetapi rerata albumin menunjukkan subjek berada pada kondisi hipoalbuminemia (albumin kurang dari 3,5 mg/dL). Rentang kadar albumin $2 \mathrm{~g} / \mathrm{dL}-4,2 \mathrm{~g} / \mathrm{dL}$. Rerata lama infus kelompok kasus tidak berisiko terhadap phlebitis (kurang dari 10 hari), tetapi pada kelompok kontrol berisiko terhadap kejadian phlebitis. Rentang durasi pemakaian infus adalah 3 hari hingga 59 hari dengan rerata total $10,14 \pm 5,65$ hari. Skor menurut Badan Pusat Statistik (BPS) menunjukkan bahwa rerata subjek memiliki sosial ekonomi yang cukup. Secara keseluruhan tidak terdapat perbedaan karakteristik kelompok kasus dan kelompok kontrol ( $\mathrm{p}>0.05)$, kecuali skor BPS.

Sebagian besar mata pencaharian ayah pasien adalah pegawai swasta dan buruh tukang, sedangkan mayoritas 
ibu pasien tidak bekerja. Lebih dari separuh subjek berpenghasilan antara Rp. 400 000,00 - Rp. 800 000,00. Duabelas orang (23\%) memiliki penghasilan di atas upah minimum regional (UMR) untuk kota Semarang tahun 2010, yaitu Rp. 961 323,00. ${ }^{11}$

Tigapuluh sembilan (75\%) subjek mendapatkan terapi leukemia risiko standar, sedangkan sisanya mendapatkan terapi risiko tinggi. Status gizi subjek diukur berdasarkan indeks masa tubuh (IMT) menurut umur pada saat anak pertama kali dirawat di rumah sakit. Enam belas (30\%) subjek mempunyai IMT kurang dari -2 SD, menurut WHO Anthro 2005 berarti subjek tersebut berada dalam kategori kurus. Secara keseluruhan rerata IMT adalah $-1,17 \pm 1,7 \mathrm{SD}$, yang terdiri dari kelompok kasus $(-1,46 \pm 1,62)$, dan kontrol $(-0,88 \pm 1,78)$. Berdasarkan uji chi square antara BMI menurut umur dengan kejadian demam neutropenia, tidak didapatkan hubungan yang bermakna antara IMT underweight dan normal pada kelompok $(\mathrm{p}=0,382)$.

Kami menggunakan kuesioner untuk menentukan status sosial ekonomi berdasarkan BPS tahun 2008. Terdapat 14 kriteria miskin BPS, apabila skor $>9$

Tabel 1. Karakteristik subyek pada kedua kelompok

\begin{tabular}{lccc}
\hline Variabel & Kasus & Kontrol & Total \\
\hline Jenis kelamin (n. \%) & & & \\
$\quad$ Laki-laki & $13(25,0)$ & $18(34,6)$ & $31(59,6)$ \\
$\quad$ Perempuan & $8(15,4)$ & $13(25,0)$ & $21(40,4)$ \\
Umur (tahun) & $6,02 \pm 3,7$ & $6,22 \pm 3,6$ & $6,12 \pm 3,65$ \\
Jenis leukemia (n. \%) & & & \\
$\quad$ L1 & $19(36,5)$ & $22(42,3)$ & $41(78,8)$ \\
L2 & $5(9,6)$ & $2(3,8)$ & $7(13,5)$ \\
L3 & $2(3,8)$ & $1(1,9)$ & $3(5,8)$ \\
Status gizi (rerata \pm SB) & & & \\
$\quad$ IMT (indeks massa tubuh) & $-1,5 \pm 1,62$ & $-0,9 \pm 1,78$ & $-1,2 \pm 1,71$ \\
Albumin (g/dL) & $3,2 \pm 0,56$ & $3,3 \pm 0,46$ & $3,2 \pm 0,51$ \\
Rerata lama infus (hari) & $9,0 \pm 5,03$ & $11,3 \pm 6,11$ & $10,1 \pm 5,65$ \\
Skor BPS & $7,1 \pm 3,91$ & $5,1 \pm 3,17$ & $6,1 \pm 3,68$ \\
\hline
\end{tabular}

BPS: Badan pusat statistik

Tabel 2. Karakteristik orang tua subjek penelitian pada kedua kelompok

\begin{tabular}{|c|c|c|c|c|c|c|c|}
\hline \multirow{3}{*}{$\begin{array}{l}\text { Karakteristik } \\
\text { Pekerjaan ayah }\end{array}$} & \multicolumn{6}{|c|}{$\mathrm{n}(\%)$} & \multirow{3}{*}{$\frac{\mathrm{p}^{*}}{0,991}$} \\
\hline & \multicolumn{2}{|c|}{ Kasus } & \multicolumn{2}{|c|}{ Kontrol } & \multicolumn{2}{|c|}{ Total } & \\
\hline & & & & & & & \\
\hline PNS & 2 & $(3,8)$ & 2 & $(3,8)$ & 4 & $(7,7)$ & \\
\hline Buruh/tukang & 10 & $(19,2)$ & 9 & $(17.3)$ & 19 & $(36,5)$ & \\
\hline Pegawai swasta & 9 & $(17,3)$ & 10 & $(19,2)$ & 19 & $(36,5)$ & \\
\hline Wiraswasta/pedagang & 5 & $(9,6)$ & 5 & $(9,6)$ & 10 & $(19,2)$ & \\
\hline Pekerjaan ibu & & & & & & & 0,291 \\
\hline PNS & 22 & $(42,3)$ & 21 & $(40,4)$ & 43 & $(82,7)$ & \\
\hline Buruh/tukang & 0 & (0) & 1 & $(1,9)$ & 1 & $(1,9)$ & \\
\hline Pegawai swasta & 4 & $(7,7)$ & 2 & $(3,8)$ & 6 & $(11,5)$ & \\
\hline Wiraswasta/pedagang & 0 & (0) & 2 & $(3,8)$ & 2 & $(3,8)$ & \\
\hline Penghasilan orang tua & & & & & & & 1,000 \\
\hline Di bawah UMR & 20 & $(38,5)$ & 20 & $(38,5)$ & 40 & $(76,9)$ & \\
\hline Di atas UMR & 6 & $(11,5)$ & 6 & $(11,5)$ & 12 & $(23,1)$ & \\
\hline
\end{tabular}

* diuji dengan pearson $x^{2}$, *UMR: upah minimum regional 
MMDEAH Hapsari dkk: Faktor risiko terjadinya demam neutropenia pada anak leukemia limfoblastik akut

Tabel 3. Faktor risiko terjadinya demam neutropenia pada kedua kelompok

\begin{tabular}{|c|c|c|c|c|c|}
\hline Faktor risiko & Kasus n (\%) & Kontrol n (\%) & OR & $95 \% \mathrm{CI}$ & $\mathrm{p}^{*}$ \\
\hline \multicolumn{6}{|c|}{ Dosis kemoterapi sitostatika } \\
\hline Risiko tinggi & $4(15,4)$ & $9(34,6)$ & 2,564 & $0,09-1,308$ & 0,109 \\
\hline Risiko standar & $22(84,4)$ & $17(65,4)$ & & & \\
\hline \multicolumn{6}{|l|}{ Status gizi } \\
\hline Underweight & $9(34,6)$ & $7(26,9)$ & 0,361 & $0,439-4,699$ & 0,382 \\
\hline Normal & $17(65,9)$ & $19(73,1)$ & & & \\
\hline \multicolumn{6}{|l|}{ Status sosial ekonomi } \\
\hline Miskin & $11(42,3)$ & $4(14,4)$ & 4,591 & $1,078-15,086$ & 0,032 \\
\hline Tidak miskin & $15(57,7)$ & $22(84,6)$ & & & \\
\hline \multicolumn{6}{|c|}{ Rerata durasi pemakaian infus hari } \\
\hline$>10$ & $6(23,1)$ & $5(19,2)$ & 0,115 & $0,442-4,790$ & 0,500 \\
\hline$<10$ & $20(76,9)$ & $21(80,8)$ & & & \\
\hline \multicolumn{6}{|l|}{ Kadar albumin } \\
\hline Hipoalbuminemia & $20(76,9)$ & $17(65,4)$ & 0,843 & $0,522-5,969$ & 0,271 \\
\hline Normal & $6(23,1)$ & $9(34,6)$ & & & \\
\hline
\end{tabular}

* diuji dengan pearson $x^{2}$

Tabel 4. Analisis multivarian faktor risiko kejadian demam neutropenia $(\mathrm{n}=52)$

\begin{tabular}{lcccc}
\hline \multirow{2}{*}{ Variabel } & \multirow{2}{*}{ Adj. OR } & \multicolumn{2}{c}{$95 \% \mathrm{CI}$} & \multirow{2}{*}{$\mathrm{p}$} \\
\cline { 3 - 4 } & & Terendah & Tertinggi & \\
\hline Durasi pemasangan infus & 0,754 & 0,152 & 3,750 & 0,730 \\
IMT/umur & 1,001 & 0,120 & 8,347 & 0,999 \\
Sosial ekonomi & 0,286 & 0,066 & 1,248 & 0,096 \\
Dosis terapi sitostatika & 2,769 & 0,535 & 14,325 & 0,225 \\
Kadar albumin & 0,896 & 0,203 & 3,956 & 0,885 \\
Albumin*IMT & 0,922 & 0,770 & 1,104 & 0,379 \\
\hline
\end{tabular}

dianggap miskin. ${ }^{12}$ Terdapat $15(28,8 \%)$ subjek dari keseluruhan yang diteliti, termasuk kategori miskin. Durasi pemakaian infus dibagi 2 kategori, yaitu $>10$ hari dan $<10$ hari oleh karena batasan ini merupakan faktor risiko kejadian phlebitis. ${ }^{2,13}$ Sebagian besar subyek terpasang infus kurang dari 10 hari, baik pada kelompok kasus dan kelompok kontrol. Tiga perempat subjek penelitian memiliki kadar albumin di dalam darah $<3,5 \mathrm{~g} / \mathrm{dL}$ (hipoalbuminemia).

Hasil uji statistik menunjukkan terdapat hubungan yang bermakna antara status sosial ekonomi dengan kejadian demam neutropenia dengan nilai OR sebesar 4,591 kali dibandingkan pasien yang tidak miskin. Tidak terdapat hubungan yang bermakna antara dosis kemoterapi sitostatika, status gizi, status sosial ekonomi, rerata durasi pemakaian infus, dan kadar albumin dengan kejadian demam neutropenia. Anali- sis besar risiko menunjukkan bahwa dosis kemoterapi sitostatika, status gizi, status sosial ekonomi, rerata durasi pemakaian infus dan kadar albumin bukan merupakan faktor risiko maupun faktor protektif terhadap kejadian neutropenia.

Analisis multivariat terhadap semua faktor risiko demam neutropenia pada LLA, yaitu lama pemasangan infus, kadar albumin, status gizi, status sosial ekonomi, dosis sitostatika dilakukan dengan menggunakan uji regresi logistik. Dilakukan analisis terhadap model regresi dengan memasukkan IMT menurut umur sebagai representasi status gizi

Status sosial ekonomi merupakan faktor terbesar derajat kemaknaannya terhadap kejadian neutropenia dibandingkan dengan faktor risiko lainnya $(\mathrm{p}=0,096)$ (Tabel 4). Indeks massa tubuh (IMT)/umur merupakan faktor risiko terkecil derajat kemaknaannya 
terhadap kejadian demam neutropenia $(\mathrm{p}=0,999)$. Hasil analisis multivariat tersebut tidak didapatkan adanya faktor risiko yang berpengaruh terhadap kejadian demam neutropenia $(\mathrm{p}>0,05)$

\section{Pembahasan}

Proporsi pasien berjenis kelamin perempuan dua pertiga dari jumlah pasien laki-laki. Berbeda dengan penelitian Al-Akhwal $\mathrm{dkk}^{14}$ di Saudi Arabia, jumlah laki-laki dan perempuan lebih banyak daripada lakilaki. Menurut Lyman dkk $^{15}$ jenis kelamin perempuan memiliki risiko sebesar 1,32 kali terhadap terjadinya demam neutropenia.

Dosis kemoterapi risiko tinggi bukan merupakan faktor risiko terhadap LLA, berbeda dengan beberapa kepustakan sebelumnya. Penelitian pada anak masih sangat terbatas, tetapi penelitian sebelumnya oleh Linker $\mathrm{dkk}^{16}$ pada orang dewasa dengan jumlah sampel 84 pasien, ditemukan bahwa kemoterapi risiko tinggi meningkatkan risiko terjadinya demam neutropenia. Namun, Sharma dkk ${ }^{17}$ dalam artikelnya menyatakan bahwa kemoterapi merupakan faktor risiko. Hal tersebut kemungkinan disebabkan karena perbedaan umur dan jumlah sampel, perbedaan protokol kemoterapi juga sangat berperan dalam terjadinya demam neutropenia. Protokol terapi risiko standar dan risiko tinggi berbeda pada fase reinduksi. Fase reinduksi pada risiko tinggi diduga menjadi faktor protektif terjadinya demam neutropenia oleh karena lebih aktif membunuh sel ganas sehingga mengurangi infiltrasi sel-sel ganas di sumsum tulang. Pasien demam neutropenia yang mengalami demam selama 4-7 hari dan telah diberi antibiotik, tetap memiliki risiko yang tinggi terhadap infeksi jamur invasif. ${ }^{17}$

Demam neutropenia yang diakibatkan oleh masalah status gizi jarang terjadi di luar negeri. Masalah gizi yang terkait dengan demam neutropenia pada umumnya disebabkan oleh defisiensi vitamin B12 atau asam folat, gangguan proses pembentukan DNA, dan kekurangan mikronutrien tembaga $(\mathrm{Cu}) .^{18,19}$ Penelitian kami menunjukkan bahwa sebagian besar status gizi pasien LLA berkategori normal dengan proporsi antara underweight dan normal 1:2,38. Proporsi yang lebih dari 1:2 mengakibatkan hasil uji statistik menunjukkan bahwa IMT menurut umur bukan merupakan faktor risiko, maupun faktor protektif terhadap terjadinya demam neutropenia.
Tidak didapatkan kekurangan energi dan protein yang ekstrim pada sampel penelitian, pengukuran status gizi anak diukur berdasarkan indeks IMT menurut umur pada saat anak pertama kali dirawat di rumah sakit. Penilaian status nutrisi diakui tidak mudah karena saat ini tidak ada baku emas untuk mengukur statuus gizi. $^{20}$ Status gizi merupakan multidimensional dan dapat dievaluasi secara diet, klinis/antropometrik, maupun biokimia.

Penelitian Alexandre $\mathrm{dkk}^{18}$ melaporkan bahwa faktor nutrisi dan inflamasi meningkatkan risiko toksisitas kemoterapi. Penelitian kami menunjukkan bahwa hampir sebagian besar subjek termasuk dalam golongan miskin, tetapi tidak berada dalam gizi kurang maupun buruk. Hal tersebut sesuai dengan penelitian oleh Tanumihardjo dkk. ${ }^{21}$ Hubungan yang lemah antara nutrisi dengan penghasilan disebabkan karena anak kecil tidak membutuhkan banyak makanan, dan mereka rentan terhadap gangguan pertumbuhan oleh karena penyakit dan infeksi. Hal tersebut juga sesuai dengan hasil penelitian oleh Susilowati $\mathrm{dkk}^{22}$ didapatkan mayoritas sampel mengalami gangguan pertumbuhan pada saat awal sehingga berperawakan pendek.

Pada umumnya pasien keganasan memiliki kadar albumin kurang dari 3,5 g/dL. Kami mendapatkan rerata albumin 3,2 $\pm 0,51$ dengan rerata kelompok kasus $0,10 \mathrm{~g} / \mathrm{dL}$ lebih rendah dibandingkan dengan kelompok kontrol. Hal tersebut terjadi akibat leakage sehingga albumin keluar dari pembuluh darah, mengakibatkan kadar albumin dalam darah menjadi berkurang. Sebagian besar anak datang dengan kondisi kadar albumin rendah, kemungkinan disebabkan asupan gizi yang rendah disertai dengan meningkatnya pemakaian oleh sel kanker. Berdasarkan uji chi square didapatkan bahwa hipoalbuminemia bukan merupakan faktor risiko terhadap demam neutropenia, tidak didapati hasil yang bermakna antara status albumin dengan kejadian demam neutropenia. Hasil ini berbeda dengan temuan penelitian oleh Intragumtornchai $\mathrm{dkk}^{23}$ di Bangkok yang melaporkan bahwa kadar albumin di bawah 3,5g/dL dan 2,0 g/dL berisiko masingmasing 3,1 dan 11,2 kali untuk terjadinya demam neutropenia. Penelitian Drenick $\mathrm{dkk}^{24}$ menyatakan saat seseorang kekurangan makanan dalam jangka 1-2 bulan, terdapat penurunan jumlah neutrofil setengah dari jumlah pada keadaan normal. Albumin berperan dalam distribusi berbagai macam hormon dan obat sitostatik. Sekitar 50\%-90\% obat sitostatik berkaitan 
dengan albumin sebagai agen distribusinya. Goldwaser dan Feldman memperkirakan bahwa setiap penurunan $2,5 \mathrm{~g} / \mathrm{dL}$ serum albumin terdapat peningkatan jumlah kematian sebesar 24\%-56\%. Penelitian menyebutkan rendahnya kadar albumin dapat menunjukkan adanya reaksi radang secara akut, adanya peningkatan produksi katekolamin dan TNF sebagai respon dari keganasan menimbulkan berbagai reaksi radang, dan menyebabkan pemecahan protein dan penurunan kadar albumin. ${ }^{20}$

Penelitian yang membahas mengenai pengaruh sosial ekonomi terhadap demam neutropenia masih sangat sedikit. Akan tetapi, diasumsikan bahwa sosial ekonomi secara tidak langsung berhubungan dengan rendahnya higiene sanitasi dan pendidikan orang tua yang berakibat peningkatan paparan terhadap berbagai mancam infeksi dan bahan mutagenik dari lingkungan. Penelitian Basu dkk ${ }^{25}$ di Amerika Serikat, disebutkan bahwa faktor sosial ekonomi dapat menjadi pengganti faktor ras terhadap perburukan demam neutropenia yang diuji secara multivariat. Hasil penelitian kami, tampak bahwa faktor sosial ekonomi berhubungan secara bermakna terhadap kejadian demam neutropenia. Pasien dengan status ekonomi miskin berdasarkan kategori BPS memiliki risiko sebesar 4,59 kali untuk terjadinya demam neutropenia dibandingkan dengan yang tidak miskin.

Pasien keganasan mengalami penurunan daya tahan tubuh sehingga meningkatkan risiko kejadian infeksi, termasuk phlebitis akibat pemakaian infus. Penelitian kami tidak mendapatkan perbedaan antara rerata lama pemakaian infus lebih dari 10 hari dan kurang dari 10 hari terhadap kejadian demam neutropenia. Durasi pemakaian infus sebagai faktor risiko terhadap demam neutropenia juga tidak terbukti. Donowitz dkk menemukan bahwa dari 100 pemasangan infus dijumpai rerata infeksi sebesar 0,2 kasus $(95 \% \mathrm{CI}=0,1-0,3)$. Namun, proporsi semakin menurun hingga 0,6 kasus per 1000 hari pemasangan infus $(95 \% \mathrm{CI}=0,3-1,2)$ kejadian infeksi. Penelitian oleh Junqueira ${ }^{26}$ mengatakan bahwa demam neutropenia tidak meningkatkan risiko untuk terjadinya infeksi bakteri terkait dengan kateter.

Analisis multivariat dalam penelitian kami menggunakan metode regresi logistik. Sosial ekonomi merupakan faktor yang paling berpengaruh di antara faktor risiko lainnya. Hal tersebut menunjukkan bahwa faktor sosial ekonomi berperan penting terhadap kejadian demam neutropenia yang diasumsikan terkait dengan higiene sanitasi. Faktor sosial ekonomi secara tidak langsung juga terkait dengan pola asuh, akses kesehatan, dan asupan makanan anak dalam keluarga. Belum terdapat studi yang menganalisis faktor risiko sosial ekonomi, durasi pemakaian infus, hipoalbumin, status gizi, dan dosis kemoterapi sebagai faktor risiko secara bersama-sama terhadap kejadian demam neutropenia. Oleh karena itu, analisis multivariat ini tidak dapat dibandingkan dengan penelitian sebelumnya.

Penelitian kami memiliki beberapa keterbatasan, antara lain 1). tidak meneliti adanya phlebitis, ataupun infeksi lokal lain pada pasien demam neutropenia untuk variabel durasi pemakaian infus., 2). tidak didapatkan sampel yang cukup untuk memenuhi sampel minimal untuk durasi pemakaian infus. 3). tidak melakukan pemeriksaan kadar interleukin 1, interleukin 6, INF, TNF, PGE2, dan indeks DNA yang terdapat dalam kerangka teori oleh karena keterbatasan biaya.

\section{Kesimpulan}

Status sosial ekonomi merupakan faktor risiko yang berpengaruh terhadap terjadinya demam neutropenia pada anak dengan LLA yang dirawat di Bangsal Hematologi Anak RSUP dr. Kariadi, Semarang. Disarankan perlunya penelitian multisenter kohort lanjutan untuk mengidentifikasi faktor-faktor risiko dan onset terjadinya demam neutropenia di Indonesia. Menganalisis faktor risiko lain yang berpotensi menyebabkan demam neutropenia, antara lain fokus infeksi, gangguan fungsi organ, tekanan darah, dan lain sebagainya.

\section{Daftar pustaka}

1. Permono B, Ugrasena I. Leukemia akut. Dalam: Pramono B, Sutaryo, Ugrasena I, Windiastuti E, Abdulsalam M, penyunting. Buku Ajar Hematologi-Onkologi Anak. Jakarta: Badan Penerbit IDAI; 2005. h. 236-47.

2. Mendes AV, Sapolnik R, Mendonca N. New guidelines for the clinical management of febrile neutropenia and sepsis in pediatric oncology patients. J Pediatr (Rio J) 2007; 83:S54-63.

3. Klastersky J, Paesmans M, Rubenstein EB, Boyer M, Elting L, Feld R, dkk. The multinational association 
for supportive care in cancer risk index: a multinational scoring system for identifying low-risk febrile neutropenic cancer patients. J Clin Oncol 2000;18:3038-51.

4. Hughes WT, Armstrong D, Bodey GP, Bow EJ, Brown AE, Calandra T, dkk. Guidelines for the use of antimicrobial agents in neutropenic patients with cancer. Clin Infect Dis 2002;34:730-51.

5. Behrman RE, Kliegman R, Nelson WE. Infection in the immunocompromised. nelson essentials of pediatrics. Edisi ke-5. Philadelphia: W.B. Saunders; 2006. h. 95867.

6. Dalal S, Zhukovsky DS. Pathophysiology and management of fever. J Support Oncol 2006;4:9-16.

7. Bosnjak S. Treatment of a febrile neutropenic patient. Arch Oncol. [symposium article] 2004;12:179-81.

8. Hughes WT, Armstrong D, Bodey GP, Brown AE, Edwards JE, Feld R, dkk. Guidelines for the use of antimicrobial agents in neutropenic patients with unexplained fever. Infectious diseases society of America. Clin Infect Dis 1997;25:551-73.

9. Sipsas NV, Bodey GP, Kontoyiannis DP. Perspectives for the management of febrile neutropenic patients with cancer in the 21st century. Cancer 2005;103:1103-13.

10. Viscoli C, Varnier O, Machetti M. Infections in patients with febrile neutropenia: epidemiology, microbiology, and risk stratification. Clin Infect Dis 2005;40:S2405.

11. Waluyo B. Upah minimum regional propinsi jawa tengah, non sektor pada tahun 2011. Semarang: Pemerintah Kota Semarang; 2011 [updated 11 Januari 2011; diakses 12/8 2011]; Diunduh dari: http://www.hrcentro.com/umr/ jawa_tengah/kota_semarang/non_sektor/2011.

12. Yogyakarta DSD. Kriteria untuk menentukan keluarga / rumah tangga miskin. Yogyakarta: Dinas Sosial DIY Yogyakarta; 2010 [diakses 4 2010]; Diunduh dari: http:// www.dinsos.pemda-diy.go.id/index.php?option = contentertas $k=$ vieworid=118\&Itemid $=46$.

13. Penack O, Rempf P, Eisenblatter M, Stroux A, Wagner J, Thiel E, dkk. Bloodstream Infections in neutropenic patients: early detection of pathogens and directed antimicrobial therapy due to surveillance blood cultures. Ann Oncol 2007; 18:1870-4.

14. Al-Ahwal MS, Al-Sayws F, Johar I. Febrile neutropenia comparison between solid tumours and hematological malignancies. Saudi Med J 2005:4-7.
15. Lyman GH, Lyman CH, Agboola O. Risk models for predicting chemotherapy-induced neutropenia. Oncologist 2005;10:427-37.

16. Linker C, Damon L, Ries C, Navarro W. Intensified and shortened cyclical chemotherapy for adult acute lymphoblastic leukemia. J Clin Oncol 2002; 20:2464-71.

17. Sharma A, Lokeshwar N. Febrile neutropenia in haematological malignancies. J Postgrad Med 2005;51: S42-8.

18. Alexandre J, Gross-Goupil M, Falissard B, Nguyen ML, Gornet JM, Misset JL, dkk. Evaluation of the nutritional and inflammatory status in cancer patients for the risk assessment of severe haematological toxicity following chemotherapy. Ann Oncol 2003;14:36-41.

19. Imataki O, Ohnishi H, Kitanaka A, Kubota Y, Ishida T, Tanaka T. Pancytopenia complicated with peripheral neuropathy due to copper deficiency: Clinical diagnostic review. Intern Med 2008;47:2063-5.

20. Sala A, Pencharz P, Barr RD. Children, cancer, and nutrition--a dynamic triangle in review. Cancer 2004;100:677-87.

21. Tanumihardjo SA, Anderson C, Kaufer-Horwitz M, Bode L, Emenaker NJ, Haqq AM, dkk. Poverty, obesity, and malnutrition: an international perspective recognizing the paradox. J Am Diet Assoc 2007;107:1966-72.

22. Susilowati D, Karyadi D. Malnutrition and poverty alleviation: review article. Asia Pacific J Clin Nutr 2002;11:S323-S30.

23. Intragumtornchai $T$, Sutheesophon J, Sutcharitchan P, Swasdikul D. A predictive model for life-threatening neutropenia and febrile neutropenia after the first course of chop chemotherapy in patients with aggressive nonHodgkin's lymphoma. Leuk Lymphoma 2000;37:35160 .

24. Drenick EJ, Alvarez LC. Neutropenia in prolonged fasting. Am J Clin Nutr 1971; 24:859-63.

25. Basu SK, Fernandez ID, Fisher SG, Asselin BL, Lyman GH. Length of stay and mortality associated with febrile neutropenia among children with cancer. J Clin Oncol 2005;23:7958-66.

26. Junqueira BL, Connolly B, Abla O, Tomlinson G, Amaral JG. Severe neutropenia at time of port insertion is not a risk factor for catheter-associated infections in children with acute lymphoblastic leukemia. Cancer 2010;116:4368-75. 